\title{
Public Participation Planning of Environmental Impact Assessment (EIA) and Regulations: Analysis of Inconsistency for Some Cases in Indonesia
}

\author{
Aniek Hindrayani ${ }^{1, *}$, and Purwanto ${ }^{2}$ \\ ${ }^{1}$ Department of Economic Education, Sebelas Maret University, Surakarta - Indonesia \\ ${ }^{2}$ Department of Soil Science, Sebelas Maret University, Surakarta - Indonesia
}

\begin{abstract}
The failure in community involvement during the environmental documents planning may result in the failure of the planned project implementation. This study aims to determine the gap between practices and regulations that apply to the process of community involvement in the environmental documents planning, and find out inconsistency of implementation on each stakeholder in the planning of the Environmental Impact Assessment (EIA) and the environmental permit. The method used was qualitative through interview and literature study which is analyzed using triangulation model and presented in the form of concept map. The results of the study indicate that 1) the determination of community representatives based on the criteria of the impacted communities is not clearly described, 3) suggestions, opinions, and responses to the environmental impact management are not well implemented by the project proponent, 3) implementation of the environmental management of other licensed activities affecting the behavior (4) stakeholders (project proponent, EIA consultants, and EIA appraisal committee) do not play their role as mandated in applicable legislation.
\end{abstract}

\section{Introduction}

Public consultation in the EIA study of a proposed project is a preliminary step that must be undertaken and largely determines the sustainability of the proposed project. The results show that only $40 \%$ of Indonesians participate in public consultations, and such engagement is limited to the subjective norm [1]. There are still many unclear public participation in development country caused by negative attitudes of government officials, weak public environmental awareness, weak supervision and penalty mechanism, bribery and corruption issues, political intervention, and poor economic conditions [2]. The low level of community involvement in the EIA process also occurs in Kenya's development plan which is largely due to lower policies, laws and regulations [3].

This research aims to determine the gap between practices and regulations that apply to the process of community involvement in the environmental documents planning, and find out inconsistency of implementation on each stakeholder in the planning of the Environmental Impact Assessment (EIA) and the environmental permit.

This research method is descriptive qualitative, through interview and literature study. Data analysis was done with triangulation. The results showed that the determination of community representatives based on the criteria of the impacted communities is not clearly described. Suggestions, opinions, and responses to the environmental impact management are not well implemented by the project proponent. Implementation of the environmental management of other licensed activities affecting the behavior. Stakeholders (project proponent, EIA consultants, and EIA appraisal committee) do not play their role as mandated in applicable legislation.

Furthermore, this paper discusses about literature review, research methods, results and discussion, and concludes.

\section{Literature review}

\subsection{Review of Legislation}

The regulations on public involvement are generally described in Law No.32 of 2012 and Govt. Reg. No.27 of 2012. While regulations and guidelines on the implementation of public consultation are specifically listed in the Regulation of the State Minister of the Environment No.17 of 2012. But in practice, it is often the proponent/EIA consultant ignores the objectives, principles and procedures in accordance with the law so that there is turmoil, rejection and social conflict in the pre-construction and or construction stage of the implementation of its development. As stated in the Regulation of Environment No.17 of 2012, the objectives of the Community Involvement in EIA Process are:

\footnotetext{
Corresponding author: aniekhindrayani@gmail.com
} 
a. In order to obtain information about proposed projects that have an important impact on the environment for the communities in the vicinity

b. The public may submit their suggestions, opinions and responses related to the proposed project,

c. Communities may be involved in the decisionmaking process regarding the feasibility or inappropriateness of the proposed project

d. Communities may submit their suggestions, opinions and responses on the application and issuance of environmental permit from the proposed project

Community involvement in the EIA process should be implemented on the following basic principles:

a. Providing transparent and complete information,

b. Equality of positions among the parties involved,

c. Problem solving that is fair and wise,

d. Coordination, communication and cooperation among the parties concerned.

The content in public consultations to be submitted includes:

- Name and address of the proponent;

- Location and extent of proposed project with information on administration limits from project site location and project site map;

- A detailed description of the proposed project;

- Potential environmental impacts (potential impact of initial judgment of the initiator) in the presence of a proposed project;

- Important environmental components (cultural, ecological, socioeconomic, defense, etc.) to be affected;

EIA proponents/consultants may use public methods that are considered effective and efficient to encompass public tax returns such as public meetings, workshops, seminars, focus group discussions, and other methods that can be used for two-way communication. In modern context, communication is more effective using ICT as gadget, email, or short message [4]. Communities involved in the public consultation include (1) the affected, (2) environmentalists, and (3) who are affected by all decisions in the EIA process.

\subsection{Previous research}

Community involvement is more consultative than participation. Consultations simply meet the regulations, where the activity is seeking advice from the public, while public participation more to the democratic process of discussing, thinking, deciding, planning, and playing an active part in the development and operation of services that affect their lives according to Wathern [3]. Previous research found that community involvement in EIA process specially in developing country was not yet optimum [1], [2], [3].

\subsection{Case of crude palm oil, hotel \& apartment, and cement industry}

In the case of oil palm plantations and factories, regulated in Minister of Agriculture Regulation No.98
2013 and updated with No.29 2016. The regulatory reforms eliminate some articles that generally harm the surrounding community.

In the case of hotel \& apartment, there are no specific regulations, so it refers to the more general rules of building and construction. Not far with in the cement industry, the regulations available more to the industry itself, have not specifically pointed to the affected communities.

\section{Research Methods}

This research is a qualitative descriptive research. Researchers do triangulation, i.e method, data source, and theory to analyze data. Triangulation method is done by interview and observation. Triangulation of data source is primary data of interview result and secondary data from literature study, while triangulation theory is based on literature study and previous research.

Interviews are conducted to stakeholders, in this case community representatives, appraisal commissions, and initiators. Observations were made on the EIA documents of hotel \& apartment, oil palm plantation, and cement plant. We also doing literature study of applicable regulations related to public consultation and description of activities to control policy and implementation in the field. The results of previous relevant studies are a reference for this study to strengthen the results of the analysis.

We selected several cases in Indonesia represented by palm oil plant $\&$ industry, housing $\&$ apartment, and cement industry cases in three different regions, which is in East Kalimantan, Special Region of Yogyakarta, and Central Java.

\section{Results and discussion}

Generally, in the process of community involvement, stakeholders mapping really should represent, not the amount, but represent the community that approximately support and not support the proposed project. When the consultant appoints community representatives, it is not really oriented to involve the community in exploring the suggestions, opinions, and responses to provide an opportunity for decision-making, but mostly just to meet formal requirements, the administrative has conducted public consultation.

At the time of appointment are also not described tasks and functions as a representative in capturing the aspirations of society that has not been stated/achieved during the Focus Group Discussion, so that accumulated at the end of the process of drafting environmental permit documents.

This is related to the Regulation of the Minister of Manpower No. 122 of 2016 concerning the Stipulation of Indonesian National Work Competency Standards Professional Activity, Scientific and Technical Category Other Activities Professional, Scientific and Technical Activities at the Working Position of the EIA. The process of community involvement in some cases is described below. 


\subsection{Case of crude palm oil (cpo) in east Kalimantan}

In the case of oil palm plantation, the plasma plantation gets a $20 \%$ share that should be managed by the community in the vicinity of the activity site, but in fact it is sold. According to the regulation, the distribution of smallholdings is intended to empower the community, so there is no social gap. As a result, local people look for more land in the forest, leading to deforestation. If studied from the production chart, up to the 5 th year, the garden is immature, in the next 15-20 years, peak production, then decreases to 25-30 years. In the period of production decline, the population should start replanting, but in the reality, they do not want to invest for replanting, should be some replanting, some up to 30 years, so there is sustainability.

Involving the community in the process of drafting the documents to the extent they do not have difficulty to meet basic needs and be involved in the operation of the plants and factory only. Other issues related to long-term sustainability have not been the demands of affected communities, whether they are sustainable for economic welfare or environmental conservation.

\subsection{Case of hotel \& apartment in Yogyakarta}

In the case of hotel \& apartment development plans in Special region of Yogyakarta, the main issue that arises is the occurrence of water crisis. Hotel \& apartment should not use groundwater, while there is no regulation, the consideration is only carrying capacity and capacity. While many hotels are already in operation, it becomes a cumulative impact that has not been studied in depth. Utilization of water by government department is required, while the use of ground water is only for reserves, but then the supervisor has not been well laid out.

People began to reject most of the hotel \& apartment development plans for that reason, as well as other reasons such as the use of public roads, funerals and the use of public facilities. This is caused by the lack of fulfillment of community representatives in the process of preparing EIA documents and communication between stakeholders.

\subsection{Case of cement industry in Central Java}

In the case of the cement industry, the community is not involved in the process of composing the environmental documents in its entirety, the process of involving the community is not participative, not the essence, and the socialization is not clear.

Citizens are not given the opportunity to voice violations that have been committed during the preparation of development projects

Citizens are not given the opportunity to voice violations that have been committed during the preparation of the plant construction project. Citizens do not know clear information about plant plans. There is no socialization involving the villagers in general, but only the village apparatus. Environmental documents are not give in to the residents so there is no clear explanation of the negative impacts

\subsection{Community Involvement Patterns}

The process of preparing the EIA, the application of environmental permits and the involvement of communities based on regulation is illustrated in the following concept maps:

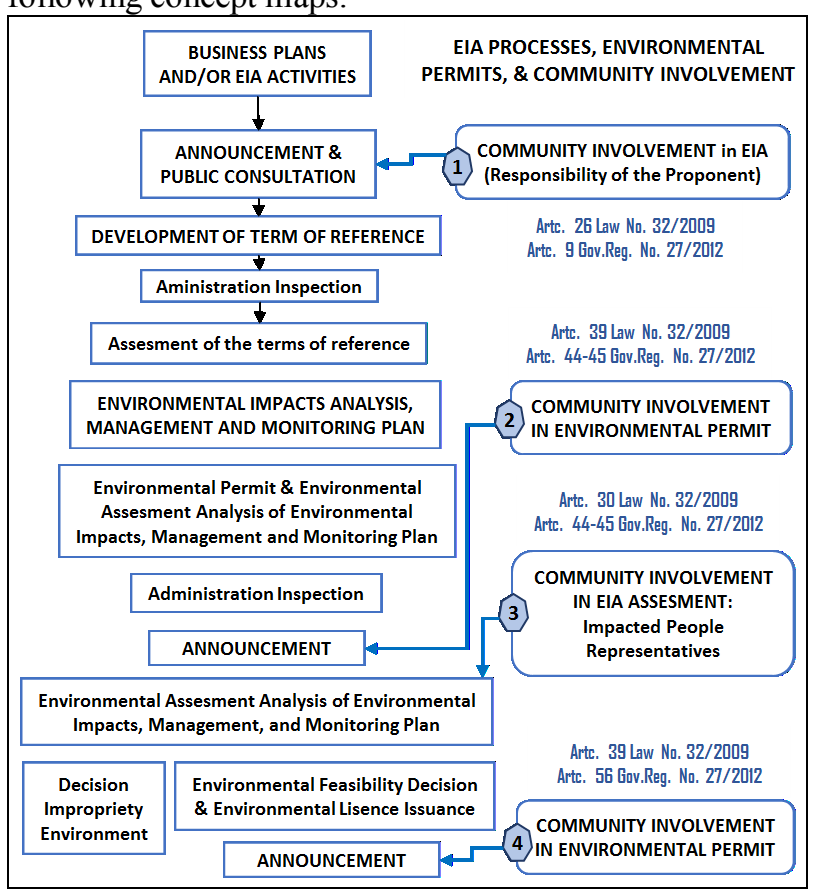

Fig 1. EIA Processes, Environmental Permits, and Community Involvement

From the figure above, we can say that in the selection of suggestions, opinions, and responses from the community, among others, determined the important hypothetical impact that needs to be studied more deeply. Communities are involved in the announcement of the environmental permit request from the proponent to the public prior to the Technical Team meeting or before the EIA Assessor Commission session. The public acts as a member of the EIA's appraisal commission in assessing documents to engage in the determination of eligibility or inadequacy of the environment. The community also plays a role to provide suggestions, opinions, and responses prior to the issuance of environmental permits.

While the mechanism of public consultation in the field should go along the following pattern as Figure 2

The consultation mechanism begins by understanding the objectives of public consultation (collecting suggestion, opinions, and response from the community regarding the planned activities, what are the expectations, concerns and concerns of the community), then planning and preparing public consultations in the form of facilities and infrastructure, who will be invited / stakeholders mapping to be true representing a wide range of affected communities, stakeholder consultation mapping and public consultation exercises to gain legitimacy from local formal leaders). 


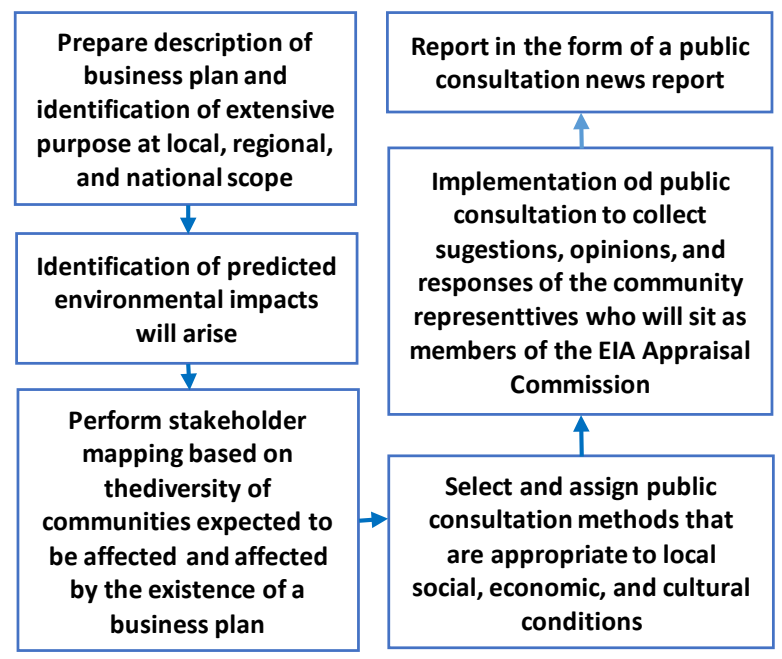

Fig 2. Consultation Mechanism

The consultant/proponent predicts significant impacts that will arise (as part of the socialization material), identify areas of consultation (field orientation and limited interviews with key figures), determine the objectives of the consultation (who will be invited to the public consultation and who is expected to become community representatives as members of EIA assessment commission). Next is to prepare an information exchange plan, by preparing the most effective media, forms, and methods of public consultation according to the level of education and local cultural conditions, selecting consultation techniques, establishing places, dates, techniques and methods of public consultation after obtaining input from local community leaders, and implementation of public consultations. Last is to summarize suggestions, opinions and community responses to be reported in terms of reference to the EIA commission.

Anticipating the implications of the ineffectiveness of community involvement processes can be done in the following way (Table 1):

Tabel 1. Problems in EIA Process and Solution Alternatives

\begin{tabular}{|c|c|c|}
\hline No & Problems & Solution Alternatives \\
\hline 1 & $\begin{array}{l}\text { The project plan } \\
\text { will be rejected }\end{array}$ & $\begin{array}{l}\text { Reminds the scope of the } \\
\text { problem } \\
\text { Learn the groups that resist } \\
\text { and object to activity plan }\end{array}$ \\
\hline 2 & $\begin{array}{l}\text { The project does } \\
\text { not meet the } \\
\text { expectations of the } \\
\text { community }\end{array}$ & $\begin{array}{l}\text { Expressed to the public, that } \\
\text { suggestions will be considered } \\
\text { \& discussed with the Regional } \\
\text { Government } \\
\text { - Describe project limitations }\end{array}$ \\
\hline 3 & $\begin{array}{l}\text { Your project will } \\
\text { be stunted }\end{array}$ & $\begin{array}{l}\text { Community consultation } \\
\text { preparation of social survey } \\
\text { - Careful scheduling }\end{array}$ \\
\hline 4 & $\begin{array}{l}\text { The project plan } \\
\text { confronts itself } \\
\text { with the } \\
\text { community }\end{array}$ & $\begin{array}{l}\text { Ask the local government for } \\
\text { help to organize a meeting } \\
\text { forum } \\
\text { Make sure the apparatus } \\
\text { understands the purpose of the } \\
\text { consultation }\end{array}$ \\
\hline 5 & $\begin{array}{l}\text { Project budget } \\
\text { enlarged }\end{array}$ & - Good budget planning \\
\hline
\end{tabular}

\section{Conclusions}

Community involvement in the preparation of environmental documents is essential to EIA. This research aims to find the inconsistency between practices and regulations that apply to the process of community involvement in the environmental documents planning, and find out the implementation on each stakeholder in the process of the Environmental Impact Assessment (EIA) and the environmental permit. We used triangulation in qualitative methods analyzed the data.

The result of this study showed that in the preparation of environmental documents, communities were not included from the applicable regulations, such as participatory, non-essential, and no socialization. Stakeholder mapping has not really representation of the community that is predicted to support and reject the proposed project. When appointing community representatives, consultants, and technical teams, it does not really show the principal task and its function as a "representative" that shows the legitimacy of society. The appointment of community representatives is still carried out by consultants and technical teams, who should be chosen by the community itself.

On community empowerment, which should be provided to empower communities for sustainable prosperity, but not fully implemented, leading to deterioration in economic conditions and social inequalities, and environmental degradation. There is a gap between carrying capacity and implementation of policies and regulations. For the stakeholders, especially the EIA assessment commission, there are no legal consequences. Further research need to accomplished with more cases to enrich the discussion.

\section{References}

1. R. Nadlifatin, M. Razif, S. Lin, SF. Persada, P.F. Belgiawa. PES. 28. 3-10. (2015)

2. J. Chen. Public Participation Provision in EIA Legal System. Master Thesis. Universiteit Utrecht. (2013)

3. D. N. Ngonge. Evaluation of Public Participation in EIA of The Southren Bypass Road in Nairobi, Kenya. A Thesis. (2015)

4. S.F. Persada, S. Lin, R. Nadlifatin, M. Razif. Open Access JIS. (2015)

5. A. Marzuki. TERUM. 3(12). 126-136. (2009)

6. C. Wasseman, Application of Public Participation in Environmental Management in Indonesia. (2012)

7. C. Wood. New Directions in Impact Assessment for Development. (2003)

8. D. Annadale. Impact Assessment and Project Appraisal. 19 (3). 187-193. (2001)

9. D. Y. Khalajabadi. A Thesis. (1994)

10. G. O'Faircheallaigh. EIAR. 30. 19-27. (2010)

11. J.O. Kakonge. Impact Assessment. 14 (3). 309-320. (2012)

12. S. Bastidas. Canadian Trade Policy. (2004) 
13. S. Momtaz. The Intl. Journal of Environmental, Cultural, Economic, \& Social Sustainability. 2(4). (2006)
14. T. Webler, H. Kastenholz, O. Rena. MEP. 443-463. (1995)

15. Y. Rahmatwati. Kompasiana, April 4, 2017. 